\title{
Nutrient requirements of rat embryos undergoing organogenesis in vitro
}

\author{
D. L. Cockroft \\ Physiological Laboratory, Cambridge CB2 3EG, U.K.
}

\begin{abstract}
Summary. Rat embryos at the head-fold stage were cultured in rotating bottles for 2 days in rat serum extensively dialysed against glucose-free BSS, and to which various energy sources and nutrients were added. Optimum growth and differentiation, virtually identical with that obtained in whole serum and to that seen during the corresponding period in vivo, were obtained with the addition of glucose and certain vitamins: pantothenic acid and riboflavin had a general beneficial effect on development, i-inositol suppressed neural tube defects, and folic acid significantly improved growth of the embryos.
\end{abstract}

\section{Introduction}

Gradual improvements in culture techniques have made it possible to achieve growth and differentiation of the pre-somite head-fold stage rat embryo in vitro at a rate almost identical to that seen in vivo for a 48-h period (New, Coppola \& Cockroft, 1976b). Hitherto, such good development has been possible only in media containing whole rat serum, although some dilution with a simple balanced salt solution is feasible without adverse effect (Cockroft \& Coppola, 1977). At other stages of post-implantation development, or for culture of the embryos of other species, dilution or supplementation of the serum may actually be beneficial (e.g. Givelber \& DiPaolo, 1968; Cockroft, 1973; Kochhar, 1975), but a proportion of whole serum has always been found to be necessary. However, Gunberg (1976) cultured rat embryos in a semi-defined medium for 21 h during which they developed from the 6-9 somite stage at explanation to about 16-18 somites. The medium consisted of whole rat serum dialysed against glucose-free balanced salt solution, and was supplemented with a range of energy substrates. The best development was obtained when both glucose and pyruvate were added to the dialysed serum. In this paper, the nutrient requirements of rat embryos during the 2-day period from head-fold to 26-27somite stage were investigated. This period is very important in the development of the embryo as it encompasses the main processes of organogenesis (e.g. formation of the first 26-27 somites, the central nervous system, sensory structures, a beating heart and blood circulation, forelimb buds), and it is also a time of considerable growth (at least 30 -fold in terms of embryonic protein content).

\section{Materials and Methods}

The rats used initially were of the CFHB strain from Anglia Laboratory Animals Ltd, Huntingdon, U.K., but this company ceased trading and it was necessary to change to the related Wistar strain (Olac 1976 Ltd, Bicester, U.K.). No difference between the two strains was apparent. Female rats were killed by cervical dislocation on the morning of the 10th day of pregnancy, and the embryos were explanted as described previously (New, 1971). After removal of the decidua and rupture of Reichert's membrane, the embryos from each litter were divided equally between culture bottles containing whole rat serum or serum from the same pool that 
had been extensively dialysed and to which various nutrients were added. The dialysis tubing (Visking tubing, Scientific Instrument Centre Ltd, London, U.K.) was rinsed in tap water for 24 $\mathrm{h}$ before use. The serum was dialysed in batches of about $35 \mathrm{ml}$ for 4 days at $4^{\circ} \mathrm{C}$ against four 250-ml changes of constantly stirred glucose-free balanced salt solution (BSS). This BSS was based on a combination of Earle's and Tyrode's salts, and the formula is shown in Table 1. This solution was found to give better and more consistent results in preliminary experiments than either Earle's or Tyrode's saline used alone.

Table 1. Formula of the balanced salt solution used for dialysis of serum

\begin{tabular}{|c|c|}
\hline Salt & Concentration $(\mathrm{g} / \mathrm{l})$ \\
\hline $\mathrm{NaCl}$ & $6 \cdot 9$ \\
\hline $\mathrm{KCl}$ & 0.3 \\
\hline $\mathrm{MgSO}_{4} \cdot 7 \mathrm{H}_{2} \mathrm{O}$ & $0 \cdot 1$ \\
\hline $\mathrm{MgCl}_{2} \cdot 6 \mathrm{H}_{2} \mathrm{O}$ & 0.05 \\
\hline $\mathrm{NaH}_{2} \mathrm{PO}_{4} \cdot 2 \mathrm{H}_{2} \mathrm{O}$ & 0.1 \\
\hline $\mathrm{NaHCO}_{3}$ & $2 \cdot 0$ \\
\hline $\mathrm{CaCl}_{2}$ & 0.2 \\
\hline
\end{tabular}

Eight vitamins and thirteen amino acids were used in the formulations for Eagle's Minimum Essential Medium (MEM) and were obtained as liquid concentrates from Flow Laboratories Ltd (Irvine, U.K.), the glucose was obtained from Fisons Ltd (Loughborough, U.K.) and the pyruvate from Sigma London Chemical Co. Ltd (Poole, U.K.). Individual vitamins were obtained as needed in dry form from Sigma.

The culture bottles were of 30 or $60 \mathrm{ml}$ capacity and contained 3 or $6 \mathrm{ml}$ culture medium and 3 or 6 embryos respectively. The bottles were gassed initially with $5 \% \mathrm{O}_{2}, 5 \% \mathrm{CO}_{2}, 90 \% \mathrm{~N}_{2}$ which was replaced with $20 \% \mathrm{O}_{2}, 5 \% \mathrm{CO}_{2}, 75 \% \mathrm{~N}_{2}$ after $24 \mathrm{~h}$ of culture (New et al., 1976a). The bottles were incubated at $37^{\circ} \mathrm{C}$ and rotated at about $60 \mathrm{rev} . / \mathrm{min}$ throughout the 48 -h culture (New, Coppola \& Terry, 1973). At the end of culture the heart beats and blood circulations of the embryos were assessed and, after dissecting away the membranes, somite counts were made, crown-rump lengths were measured and protein contents of individual embryos, free of membranes, were determined by the method of Lowry, Rosebrough, Farr \& Randall (1951).

\section{Results}

The requirements for energy sources, vitamins and amino acids are shown in Table 2. In section A, whole serum is compared with dialysed serum supplemented with vitamins and amino acids but without a carbohydrate energy source, and the same medium with $1.5 \mathrm{mg}$ glucose $/ \mathrm{ml}(8.3$ $\mathrm{mm}), 0.25 \mathrm{mg}$ pyruvate $/ \mathrm{ml}(2.9 \mathrm{mM})$ or with glucose and pyruvate.

It is apparent that growth was minimal when there was no energy source, but the addition of glucose alone restored both growth and differentiation to control levels. The inclusion of pyruvate with glucose had an adverse effect on development and pyruvate alone supported very little development (Pl. 1, Fig. 1).

The effect of adding vitamins and/or amino acids to glucose-supplemented dialysed serum is shown in Table 2B. In the absence of vitamins, the dialysed serum was able to support very little development even when amino acids were present. With the addition of vitamins, dialysed serum supported development very similar to that obtained in whole serum, and dialysed serum containing vitamins and amino acids also gave good development (Pl. 1, Fig. 2). Hence glucose and vitamins are essential additives to dialysed serum, whereas amino acids seem relatively 


\section{PLATE 1}
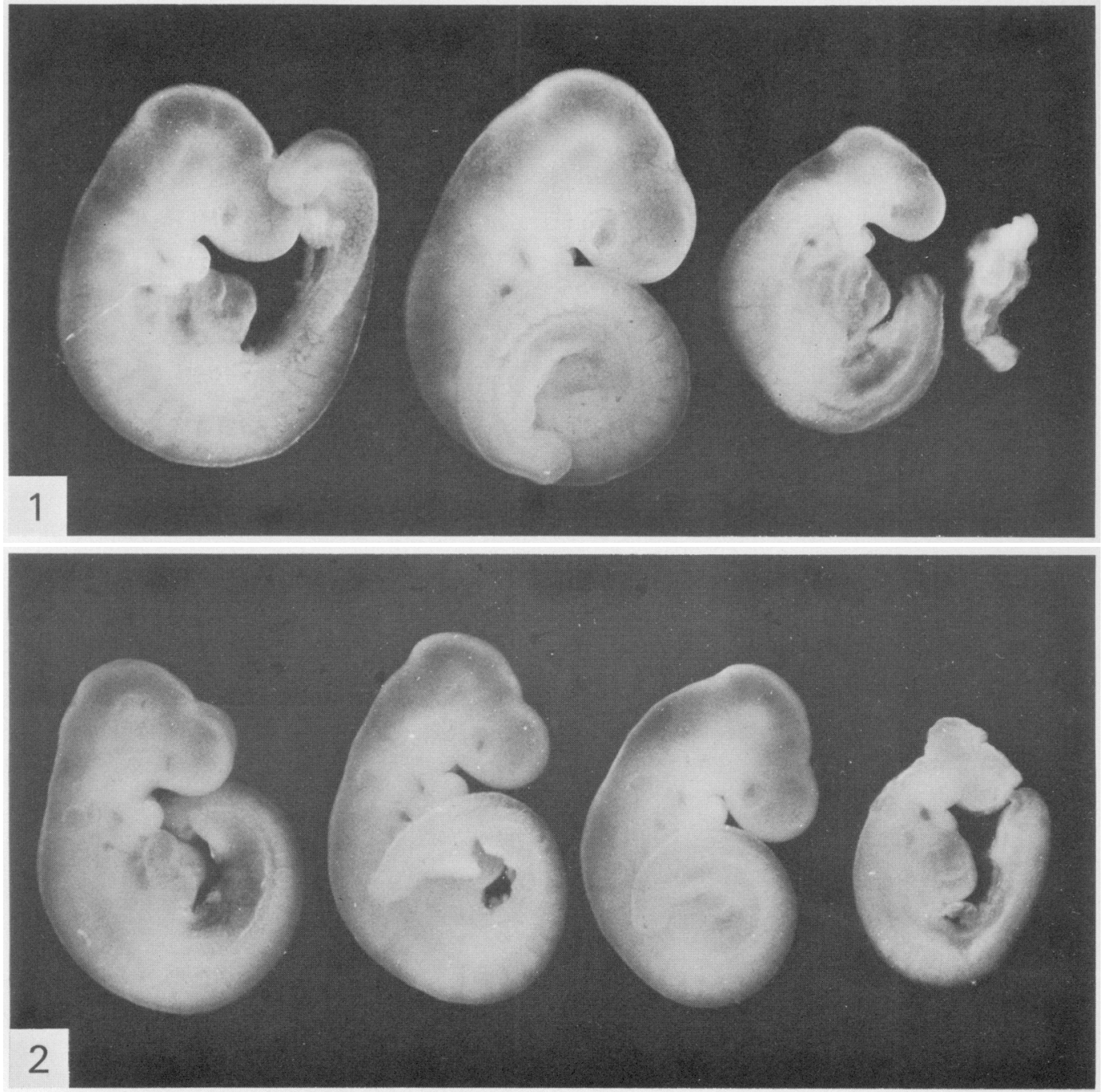

Fig. 1. Rat embryos explanted at eariy head-fold stage and cultured for $48 \mathrm{~h}$ in (from left to right) whole rat serum; dialysed serum + glucose; dialysed serum + glucose and pyruvate; dialysed serum + pyruvate. The dialysed sera were also supplemented with vitamins and amino acids. $\times 17$.

Fig. 2. Rat embryos explanted at early head-fold stage and cultured for $48 \mathrm{~h}$ in (from left to right) whole rat serum; dialysed serum + vitamins and amino acids; dialysed serum + vitamins; dialysed serum + amino acids. The dialysed sera were also supplemented with glucose. $\times 16$. 
unimportant. However, in one culture in this series the embryos in dialysed serum with vitamins and amino acids grew substantially better than those without amino acids. In the other cultures, the embryos from these two groups were identical. In combining the data, these differences are largely masked, although the crown-rump lengths of embryos cultured with vitamins and amino acids were significantly greater (at $P<0.02$ ) than those of embryos cultured without amino acids.

The vitamin preparation used contained 8 vitamins and to discover which of these are important during organogenesis, embryos were cultured in the absence of each in turn (Table $3 \mathrm{~A}$ ) and in the presence of a selection of those whose absence produced adverse effects (Table 3B).

Table 2. Mean \pm s.e.m. protein contents, somite numbers and crown-rump lengths of pre-somite rat embryos cultured for $48 \mathrm{~h}$ in whole rat serum, or dialysed serum supplemented with various combinations of glucose, pyruvate, vitamins and amino acids

\begin{tabular}{|c|c|c|c|c|c|}
\hline & & $\begin{array}{l}\text { No. of } \\
\text { embryos }\end{array}$ & $\begin{array}{l}\text { Protein } \\
(\mu \mathrm{g})\end{array}$ & $\begin{array}{l}\text { No. of } \\
\text { somites }\end{array}$ & $\begin{array}{c}\text { Crown-rump } \\
\text { length }(\mathrm{mm})\end{array}$ \\
\hline \multirow[t]{5}{*}{ (A) } & Whole serum & 12 & $158 \pm 13$ & $26 \cdot 5 \pm 0 \cdot 3$ & $3.36 \pm 0.11$ \\
\hline & Dialysed serum ${ }^{\dagger}$ & 12 & $11 \pm 1^{*}$ & - & $0.68 \pm 0.03^{*}$ \\
\hline & Dialysed serum ${ }^{\dagger}+$ glucose & 12 & $153 \pm 10$ & $26 \cdot 9 \pm 0 \cdot 3$ & $3.28 \pm 0.08$ \\
\hline & Dialysed serum + glucose + pyruvate & 12 & $108 \pm 6^{*}$ & $23 \cdot 1 \pm 0.7^{*}$ & $2.67 \pm 0.07^{*}$ \\
\hline & Dialysed serum $\dagger+$ pyruvate & 12 & $28 \pm 5^{*}$ & - & $0.62 \pm 0.02^{*}$ \\
\hline \multirow[t]{5}{*}{ (B) } & Whole serum & 18 & $177 \pm 8$ & $26.4 \pm 0.2$ & $3.23 \pm 0.07$ \\
\hline & Dialysed serum $\ddagger$ & 18 & $44 \pm 6^{*}$ & - & $1.51 \pm 0 \cdot 17^{*}$ \\
\hline & Dialysed serum $\neq+$ vitamins & 18 & $172 \pm 9$ & $26 \cdot 1 \pm 0 \cdot 5$ & $3 \cdot 15 \pm 0.08$ \\
\hline & Dialysed serum $\ddagger+$ vitamins + amino acids & 18 & $185 \pm 6$ & $27.1 \pm 0.2$ & $3.38 \pm 0.04$ \\
\hline & Dialysed serum $\neq+$ amino acids & 18 & $53 \pm 5^{*}$ & - & $1.79 \pm 0 \cdot 15^{*}$ \\
\hline
\end{tabular}

\footnotetext{
* Significantly different from value with whole serum, $P<0.001$.

$\dagger$ Including amino acids and vitamins.

$\ddagger$ Containing $1.5 \mathrm{mg}$ glucose $/ \mathrm{ml}$.
}

The single vitamin whose absence produced the most marked effect was pantothenic acid: protein content and crown-rump lengths were significantly reduced, and most of the embryos were abnormal. The embryos cultured without riboflavin showed a small but non-significant reduction in growth, and 3 were abnormal. The embryos cultured without i-inositol showed normal growth and somite number, but 3 had open neural tubes. Of the other vitamins, the poorest growth and differentiation occurred in the absence of folic acid, although again the effect was not significant. Table 3B shows the results of culturing the embryos with only these vitamins. Pantothenic acid as the sole vitamin gave considerably better development than was obtained without vitamins but protein content and somite numbers were significantly lower (at $P$ $<0.05$ and $P<0.01$ respectively) than in control medium with all 8 vitamins present, and 3 of the embryos were abnormal. Inclusion of riboflavin with pantothenate gave little improvement and again 3 embryos were abnormal. When i-inositol was added to these 2 vitamins all the embryos developed normally. When folic acid was added as a 4th vitamin, growth and somite development were significantly improved over the previous vitamin combinations, although 1 of the embryos was abnormal.

\section{Discussion}

These results show that glucose is a necessary and sufficient energy source for rat embryos undergoing organogenesis during 2 days in culture. Some vitamins are also necessary for good 


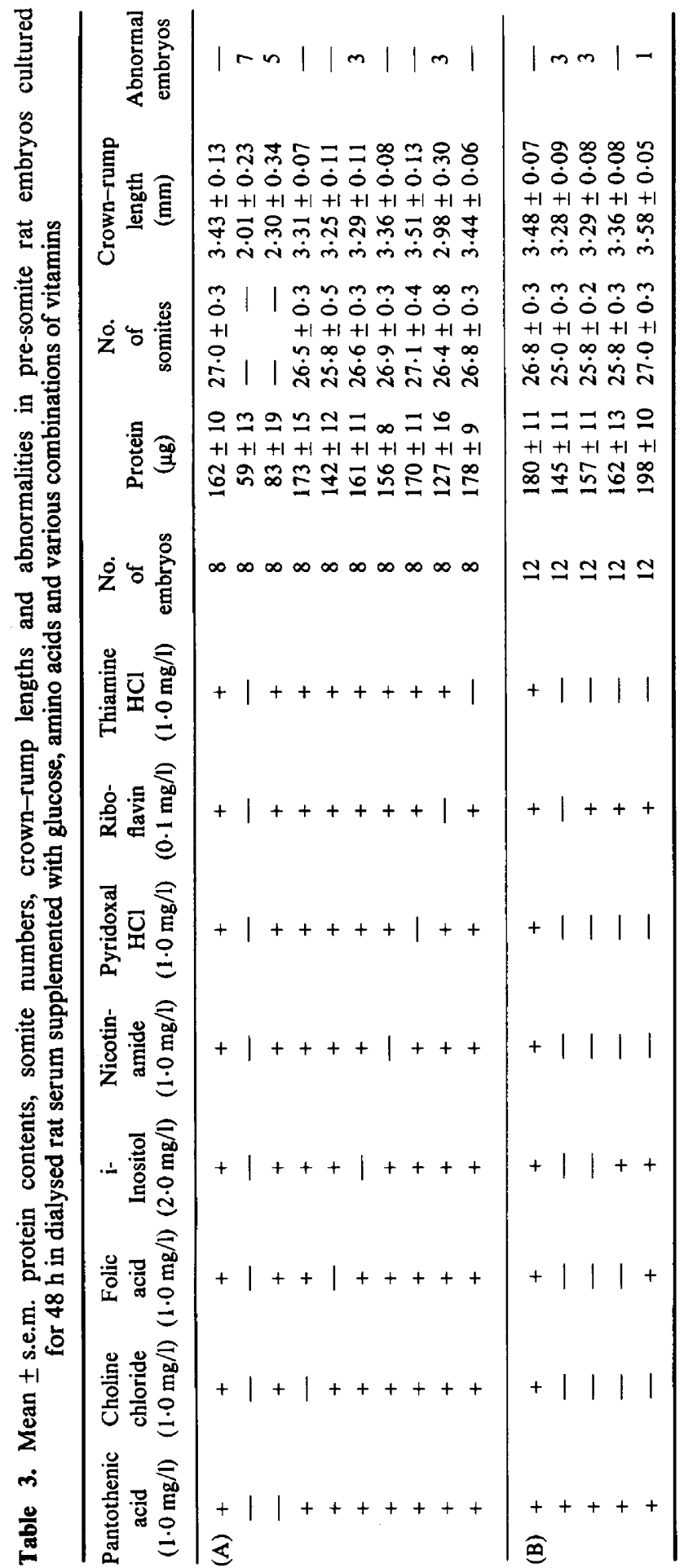


development-pantothenic acid, riboflavin, i-inositol and folic acid. The different vitamins seem to act in different ways. Pantothenate seems to be most important for both growth and normal development. Riboflavin also seems to have a general though lesser beneficial effect. In fact, the effect of riboflavin deficiency was rather variable; this may be because it is required in such small quantities (e.g. $0.27 \mu \mathrm{M}(0.1 \mathrm{mg} / \mathrm{l})$ in Eagle's MEM) that the small amounts already present in the embryos at explantation may be partly or wholly sufficient. Inositol has no effect on overall growth, but does prevent the occurrence of a specific abnormality-failure of closure of the neural tube. The one abnormal embryo in the group with folic acid seems anomalous-it may have been a spontaneous malformation. Otherwise folic acid has a clear and beneficial effect on growth of the embryos.

Fetal abnormalities caused in vitro by deficiencies of pantothenic acid, riboflavin and folic acid have been reported in pregnant rats (Woollam \& Millen, 1956; Kalter \& Warkany, 1959) although these could be a secondary effect resulting from maternal distress, a possibility that is eliminated in this in-vitro study. Discussion of the mechanisms by which such deficiencies act to produce abnormalities must be speculative, but riboflavin is necessary for the action of flavoproteins, which catalyse a wide range of biochemical reactions; pantothenic acid is a constituent of coenzyme A, important in the Krebs cycle and for fatty acid oxidation, and folic acid has a role in purine, pyrimidine, serine and glycine synthesis.

In this study pyruvate was not beneficial, indeed it seemed to be toxic. This may seem strange for a compound which is a normal intermediate in glycolysis. However, because the equilibrium for the conversion of pyruvate to lactate is so far to the right, the steady state concentration of pyruvate in cells is very low; it has been estimated at $0.17 \mathrm{~mm}$ in rat fetal liver (Hommes, 1970) and at $0.051 \mathrm{~mm}$ in human erythrocytes (Minikami, Saito, Suzuki \& Yoshikawa, 1964). In contrast, the level used here was $2.9 \mathrm{~mm}$ i.e. 17-57 times the cellular levels. Although Gunberg (1976) used an even higher dose ( $5 \mathrm{~mm})$, he did not find this adverse effect of pyruvate, possibly because he started his cultures at a later stage, when the embryos may be less sensitive, and incubated them for a much shorter period.

This study shows that with appropriate supplementation a culture medium in which the micromolecular component is defined will support both growth and differentiation of rat embryos over a critical 2-day period at rates closely comparable with those occurring in vivo. This system can be used to identify factors essential for normal development of mammalian embryos and shows that certain vitamins have quite specific effects on rat development.

I thank Dr D. A. T. New for helpful discussion, Miss P. A. Blundell for technical assistance, and the Medical Research Council for financial support.

\section{References}

Cockroft, D.L. (1973) Development in culture of rat foetuses explanted at 12.5 and 13.5 days of gestation. J. Embryol. exp. Morph. 29, 473-483.

Cockroft, D.L. \& Coppola, P.T. (1977) Teratogenic effects of excess glucose on head-fold rat embryos in culture. Teratology 16, 141-146.

Givelber, H.M. \& DiPaolo, J.A. (1968) Growth of explanted eight-day hamster embryos in circulating medium. Nature, Lond. 220, 1131-1132.

Gunberg, D.L. (1976) In vitro development of postimplantation rat embryos cultured on dialyzed rat serum. Teratology 14, 65-70.

Hommes, F.A. (1970) The control of glycolysis in fetal rat iiver. In Metabolic Pathways in Mammalian Embryos during Organogenesis and its Modification by Drugs, pp. 249-259. Eds R. Bass, F. Beck, H.-J. Merker, D. Neubert \& B. Randhahn. Freie Universität, Berlin.

Kalter, H. \& Warkany, J. (1959) Experimental production of congenital malformations in mammals by metabolic procedure. Physiol. Rev. 39, 69-1 15.

Kochhar, D.M. (1975) The use of in vitro procedures in teratology. Teratology 11, 273-288.

Lowry, O.H., Rosebrough, N.J., Farr, A.L. \& Randall, R.J. (1951) Protein measurement with the Folin phenol reagent. J. biol. Chem. 193, 265-275.

Minakami, S., Saito, T., Suzuki, C. \& Yoshikawa, H. (1964) The hydrogen ion concentrations and erythrocyte glycolysis. Biochem. Biophys. Res. Commun. 17, $748-751$. 
New, D.A.T. (1971) Methods for the culture of postimplantation embryos of rodents. In Methods in Mammalian Embryology, ch. 22, pp. 305-319. Ed. J. C. Daniel. Freeman, San Francisco.

New, D.A.T., Coppola, P.T. \& Terry, S. (1973) Culture of explanted rat embryos in rotating tubes. J. Reprod. Fert. 35, 135-138.

New, D.A.T., Coppola, P.T. \& Cockroft, D.L. (1976a) Improved development of head-fold rat embryos in culture resulting from low oxygen and modification of the culture serum. J. Reprod. Fert. 48, 219-222.
New, D.A.T., Coppola, P.T. \& Cockroft, D.L. (1976b) Comparison of growth in vitro and in vivo of postimplantation rat embryos. J. Embryol. exp. Morph. 36, 133-144.

Woollam, D.H.M. \& Millen, J.W. (1956) Role of vitamins in embryonic development. Br. med. J. June, $1262-1265$.

Received 24 April 1979 